\title{
Peran Inklusi Keuangan dalam Mengatasi Ketimpangan Pendapatan di Indonesia
}

\section{The Role of Financial Inclusion in Overcoming Income Inequality in Indonesia}

\author{
Hastina Febriaty $^{1)}$, Sri Endang Rahayu ${ }^{2)}$, Eri Yanti Nasution ${ }^{3)}$ \\ ${ }^{1)}$ Fakultas Ekonomi dan Bisnis, Universitas Muhammadiyah Sumatera Utara, Kota Medan \\ e-mail korespondensi: hastinafebriaty@umsu.ac.id
}

\begin{tabular}{|c|c|}
\hline Info A & Abstrak \\
\hline $\begin{array}{l}\text { Riwayat Artikel : } \\
\text { Diterima: } 24 \text { Februari } 2021 \\
\text { Disetujui: } 29 \text { Desember } 2021 \\
\text { Dipublikasikan: Januari } 2022\end{array}$ & $\begin{array}{l}\text { Tujuan penelitian ini adalah untuk menganalisis peran inklusi keuangan di era } \\
\text { digital ekonomi dan menghasilkan strategi dan kebijakan inklusi keuangan dalam } \\
\text { mengatasi ketimpangan pendapatan di Indonesia. Data sekunder yang digunakan } \\
\text { berupa data runtut waktu dari periode TW;1:2005 sampai TW;4:2019. Data }\end{array}$ \\
\hline $\begin{array}{l}\text { Nomor DOI } \\
\text { 10.33059/jseb.v13i1.3297 } \\
\text { Cara Mensitasi : } \\
\text { Febriaty, H., Rahayu, S. E., \& } \\
\text { Nasution, E. Y. (2022). Peran } \\
\text { inklusi keuangan dalam } \\
\text { mengatasi ketimpangan } \\
\text { pendapatan di Indonesia. } \\
\text { Jurnal Samudra Ekonomi dan } \\
\text { Bisnis, 13(1), 125-135. doi: }\end{array}$ & $\begin{array}{l}\text { bersumber dari BPS, BI dan OJK, lalu dianalisis menggunakan teknik 2SLS. } \\
\text { Hasil penelitian dalam persamaan pertama menunjukkan bahwa variabel inklusi } \\
\text { keuangan seperti jumlah rekening kredit, jumlah rekening tabungan (DPK) dan } \\
\text { jumlah kredit UMKM berpengaruh tidak signifikan terhadap pertumbuhan } \\
\text { ekonomi; sementara jumlah mesin ATM berpengaruh signifikan terhadap PE, } \\
\text { dan GR berpengaruh tidak signifikan terhadap PE. Dalam persamaan kedua, } \\
\text { variabel inklusi keuangan seperti DPK berpengaruh signifikan terhadap GR, JKB } \\
\text { berpengaruh tidak signifikan terhadap GR, serta PE berpengaruh signifikan } \\
\text { terhadap GR. }\end{array}$ \\
\hline
\end{tabular}
10.33059/jseb.v13i1.3297.

Kata Kunci: Inklusi Keuangan, Pertumbuhan Ekonomi, Ketimpangan Pendapatan, 2SLS.

\begin{tabular}{|l|}
\hline Article Info \\
\hline Article History : \\
Received: 24 February 2021 \\
Accepted: 29 December 2021 \\
Published: January 2022 \\
\hline DOI Number : \\
10.33059/jseb.v13i1.3297 \\
How to cite : \\
Febriaty, H., Rahayu, S. E., \& \\
Nasution, E. Y. (2022). Peran \\
inklusi keuangan dalam \\
mengatasi ketimpangan \\
pendapatan di Indonesia. \\
Jurnal Samudra Ekonomi dan \\
Bisnis, 13(1), 125-135. doi: \\
10.33059/ jseb.v13i1.3297.
\end{tabular}

\begin{abstract}
The aim of this study is to analyze the role of financial inclusion in the digital economy era and produce financial inclusion strategies and policies in overcoming income inequality in Indonesia. The secondary data used is in the form of time series data from the TW;1:2005 to TW;4:2019 period. The data is sourced from BPS, BI and OJK, then analyzed using the $2 S L S$ technique. The results in the first equation show that financial inclusion variables such as the number of credit accounts, the number of savings accounts (TPF) and the number of MSME loans have no significant effect on economic growth; while the number of ATM machines has a significant effect on PE, and GR has no significant effect on PE. In the second equation, financial inclusion variables such as DPK have a significant effect on GR, JKB have no significant effect on $G R$, and PE has a significant effect on $G R$.
\end{abstract}

Keywords: Financial Inclusion, Economic Growth, Income Inequality, 2SLS. 


\section{PENDAHULUAN}

Ketimpangan dalam proses distribusi pendapatan merupakan masalah perbedaan pendapatan antara golongan masyarakat atau adanya perbedaan pendapatan antara beberapa daerah yang maju dengan daerah yang tertinggal. Semakin besar jarak ketimpangan pendapatan tersebut maka akan semakin besar juga variasi dalam distribusi pendapatan. Dengan adanya situasi ketimpangan distribusi pendapatan ini, maka menyebabkan terjadinya ketimpangan antar daerah. Tentunya hal ini tidak bisa dihindari karena terdapat efek perembesan ke bawah (trickle down effect) dari pendapatan secara nasional terhadap mayoritas masyarakat yang tidak terjadi secara sempurna. Dengan demikian, hasil output secara nasional hanya dapat dinikmati oleh beberapa golongan minoritas dengan berbagai tujuan tertentu (Musfidar, 2001).

Secara spasial, struktur perekonomian Indonesia masih menghadapi ketimpangan ekonomi antar wilayah. Kontribusi terbesar terhadap produk domestik bruto tertinggi disumbang oleh Pulau Jawa sebesar 58,48 persen (BPS, 2018). Pertumbuhan ekonomi selanjutnya diikuti oleh Pulau Sumatera mencapai 21,58 persen (katadata, 2019).

Inklusi keuangan saat ini telah menjadi pertanyaan terkait dengan isu panas tentang kontribusi keuangan untuk pembangunan berkelanjutan. Penyebabnya adalah karena inklusi keuangan sudah terlihat sebagai salah satu instrumen dalam ekonomi untuk upaya mengentaskan kemiskinan, serta untuk upaya mengatasi ketimpangan atau kesenjangan yang secara signifikan meningkat di seluruh dunia. Tumbuhnya kesadaran bahwa pola pertumbuhan yang timpang memiliki batasan dan tidak berkelanjutan, karena terbatasnya permintaan aggregat. Konsekuensi sosial akan terjadi jika ketidaksetaraan ini tidak dapat ditolerir. Hal paling buruk yang bisa terjadi adalah kerusuhan sosial, yang berdampak negatif terhadap pertumbuhan ekonomi dan stabilitas sosial.

Dalam pembangunan ekonomi tingkat pendapatan per kapita akan terus-menerus meningkat, sedangkan kenaikan pertumbuhan ekonomi belum tentu diikuti oleh kenaikan pendapatan per kapita. Proses pembangunan lebih mengarah kepada arah peningkatan pertumbuhan ekonomi dan pemerataan secara optimal. Pertumbuhan ekonomi karenanya merupakan indikator yang dapat digunakan dalam melihat keberhasilan pembangunan suatu daerah (Raswita \& Utama, 2013).

Beberapa peneliti menemukan adanya hubungan bersifat positif antara pertumbuhan ekonomi dengan ketimpangan pendapatan (Chambers, 2010; Wahiba \& El-Weriemmi, 2014; Rubin \& Segal, 2015). Para peneliti tersebut menyimpulkan bahwa pertumbuhan ekonomi berhubungan positif dengan derajat ketimpangan pendapatan. Temuan empiris oleh Lundberg \& Squire (2003) serta Amri (2017) juga menemukan hasil yang sama bahwa peningkatan pertumbuhan ekonomi dapat meningkatkan ketimpangan pendapatan. Hal ini berarti dengan semakin tingginya pertumbuhan ekonomi maka ketimpangan pendapatan juga menjadi semakin tinggi; sebaliknya, menurunnya tingkat pertumbuhan ekonomi akan berdampak pada turunnya ketimpangan pendapatan.

Permasalahan inilah yang melatar belakangi pentingnya penyusunan strategi keuangan inklusif dan strategi pembangunan ekonomi secara bersinergi dalam mengatasi ketimpangan secara lebih luas. Khususnya bagi negara berkembang, dalam upaya penanggulangan ketimpangan ekonomi, tidak hanya sekedar dengan hanya meningkatkan pertumbuhan ekonomi yang bergantung pada kinerja industri nasional. Hal ini karena walaupun pertumbuhan ekonomi meningkat, namun kerap tidak berkualitas. Oleh karena itu, dengan adanya inklusi keuangan dinilai 
dapat mengatasi permasalahan ketimpangan ekonomi bagi negara-negara berkembang. Rumusan masalah utama dalam penelitian ini karenanya adalah bagaimana peran, strategi dan kebijakan inklusi keuangan di era digital ekonomi dalam mengatasi ketimpangan pendapatan di Indonesia.

\section{Pertumbuhan Ekonomi dan Ketimpangan Pendapatan}

Dalam proses perhitungan pertumbuhan ekonomi daerah menurut BPS, PDRB merupakan jumlah nilai barang dan jasa yang dihasilkan oleh seluruh unit usaha dalam suatu daerah tertentu (BPS, 2018). PDRB juga didefinisikan sebagai jumlah nilai barang dan jasa akhir (neto) yang dihasilkan oleh seluruh unit ekonomi pertumbuhan ekonomi, sehingga menggambarkan tren perkembangan aktivitas perekonomian suatu daerah.

Kesenjangan pendapatan merupakan situasi ketimpangan relatif pendapatan antar golongan masyarakat yang mereka peroleh. Kesenjangan ini dihitung menggunakan luas daerah antara garis diagonal (ketidakmerataan sempurna) yang diukur dengan Gini Ratio dengan kurva Lorenz dibandingkan dengan luas total dari separuh bujur sangkar dimana kurva Lorenz itu berada. Ukuran pemerataan pendapatan yang diukur dengan Gini Ratio mempunyai rentang angka antara 0 sampai dengan 1. Apabila nilai Gini Ratio mendekati angka nol maka menunjukkan adanya tingkat ketimpangan yang rendah; tetapi bila nilai Gini Ratio mendekati 1 maka menunjukkan ketimpangan yang relatif tinggi (Giorgi \& Gigliarano, 2016).

Kesenjangan distribusi pendapatan di negara sedang berkembang yang disebabkan oleh pertumbuhan penduduk yang tinggi akan mengakibatkan menurunnya nilai pendapatan perkapita, ketidakmerataan pembangunan antar daerah, inflasi, serta kondisi pendapatan uang bertambah tetapi tidak diikuti secara proporsional dengan pertambahan produksi barang-barang dan investasi.

\section{Inklusi Keuangan}

Dalam perkembangannya, sektor inklusi keuangan tidak hanya sebatas meningkatkan dan mengembangkan produk dan layanan jasa keuangan saja, akan tetapi juga melakukan perluasan keuangan lainnya yang meliputi empat elemen. Keempat elemen tersebut yaitu perluasan akses keuangan, ketersediaan produk dan layanan jasa keuangan, penggunaan produk dan layanan jasa keuangan, serta peningkatan kualitas baik kualitas penggunaan produk dan layanan jasa keuangan maupun kualitas produk dan layanan jasa keuangan itu sendiri.

Inklusi keuangan bisa didefinisikan sebagai anggota ekonomi dimana masyarakat mendapatkan kemudahan dalam mengakses, ketersediaan, serta penggunaan sistem keuangan formal (Sarma, 2008). Inklusi keuangan sebagai akses terhadap produk dan layanan jasa keuangan yang bermanfaat dan terjangkau dalam memenuhi kebutuhan masyarakat maupun usahanya; dalam hal ini yaitu transaksi, pembayaran, tabungan, kredit serta asuransi yang digunakan secara bertanggungjawab dan berkelanjutan (World Bank, 2016).

\section{Kerangka Penelitian}

Ummah et al. (2015) dalam studinya menemukan inklusi keuangan memiliki hubungan yang positif dan searah dengan pemerataan pendapatan di Indonesia. Lebih jauh, peneliti tersebut berargumen bahwa distribusi pendapatan pada suatu daerah mempengaruhi tingkat inklusi keuangan di daerah itu, tetapi tidak terjadi sebaliknya. Hasil studi Purba (2016) secara empiris memperoleh bahwa baik secara parsial maupun simultan, jumlah kantor bank, jumlah rekening kredit dan jumlah ATM memiliki 
pengaruh yang positif dan signifikan terhadap produk domestik bruto Indonesia. Studi milik Anwar \& Amri (2017) juga secara empiris menemukan bahwa baik secara parsial maupun simultan, inklusi keuangan yang terdiri dari jumlah kantor bank, jumlah ATM, dan jumlah rekening kredit berpengaruh positif dan signifikan terhadap PDB.

Berdasarkan telaah teoritis maupun hasil empiris terdahulu, disusun Gambar 1 yang menjabarkan kerangka pemikiran di dalam penelitian ini. Turunan dari kerangka tersebut adalah dimunculkannya dua hipotesis utama dalam metode 2 SLS, yaitu:

H1: Inklusi keuangan (JATM, JRK, JTAB, kredit UMKM) serta ketimpangan pendapatan (Gini Ratio) memiliki pengaruh secara signifikan terhadap pertumbuhan ekonomi.

H2: Inklusi keuangan (JTAB, Kredit UMKM) dan pertumbuhan ekonomi berpengaruh secara signifikan terhadap ketimpangan pendapatan (Gini Ratio).

\section{METODE PENELITIAN}

Penelitian ini menggunakan model persamaan simultan (simultaneous equations models) untuk menganalisis peran inklusi keuangan dalam mempengaruhi ketimpangan pendapatan. Dalam persamaan dari inklusi keuangan serta ketimpangan pendapatan, terdapat variabel-variabel yang dianalisis menggunakan uji t (t-test) dan uji $\mathrm{F}$ ( $F$-test). Spesifikasi model yang digunakan tersebut dijabarkan sebagai berikut:

$$
\begin{aligned}
\mathrm{PE}_{\mathrm{t}}= & \alpha_{0 \mathrm{t}}+\alpha_{1} \mathrm{JATM}_{\mathrm{t}}+\alpha_{2} \mathrm{JRK}_{\mathrm{t}}+\alpha_{3} \mathrm{JTab}_{\mathrm{t}}+ \\
& \alpha_{4} \mathrm{KUMKM}_{\mathrm{t}}+\alpha_{5} \mathrm{GR}_{\mathrm{t}}+\mathrm{e}_{\mathrm{t}} \ldots \ldots \ldots . . .(1) \\
\mathrm{GR}_{\mathrm{t}}= & \beta_{0 \mathrm{t}}+\beta_{1} \mathrm{JKB}_{\mathrm{t}}+\beta_{2} \mathrm{JTab}_{\mathrm{t}}+\beta_{3} \mathrm{PE}_{\mathrm{t}}+ \\
& \mathrm{U}_{\mathrm{t}} \ldots \ldots \ldots \ldots \ldots \ldots \ldots \ldots \ldots \ldots \ldots \ldots \ldots \ldots \ldots \ldots \ldots \ldots \ldots \ldots \ldots \ldots \ldots \ldots \ldots \ldots \ldots \ldots
\end{aligned}
$$

dimana $\mathrm{PE}_{\mathrm{t}}$ yaitu pertumbuhan ekonomi tahun $t$ (persen); $\mathrm{JATM}_{\mathrm{t}}$ adalah jumlah mesin ATM per 100.000 penduduk dewasa tahun $t$ (unit); $\mathrm{JRK}_{\mathrm{t}}$ adalah jumlah rekening kredit (kredit yang disalurkan) per 100.000 penduduk dewasa tahun $t$ (rekening/account); $\mathrm{JTab}_{\mathrm{t}}$ adalah jumlah rekening dana pihak ketiga (DPK) di Indonesia tahun $t$ (rekening/ account); $\mathrm{JKB}_{\mathrm{t}}$ adalah jumlah kantor layanan bank di Indonesia per 100.000 penduduk tahun (unit); KUMKM ${ }_{\mathrm{t}}$ adalah kredit UMKM terhadap total kredit perbankan tahun $t$ (persen); $\mathrm{GR}_{\mathrm{t}}$ adalah Gini Ratio atau ketimpangan pendapatan tahun $t$ (persen); serta, $e_{t}$ dan $\mathrm{U}_{\mathrm{t}}$ yaitu error term.

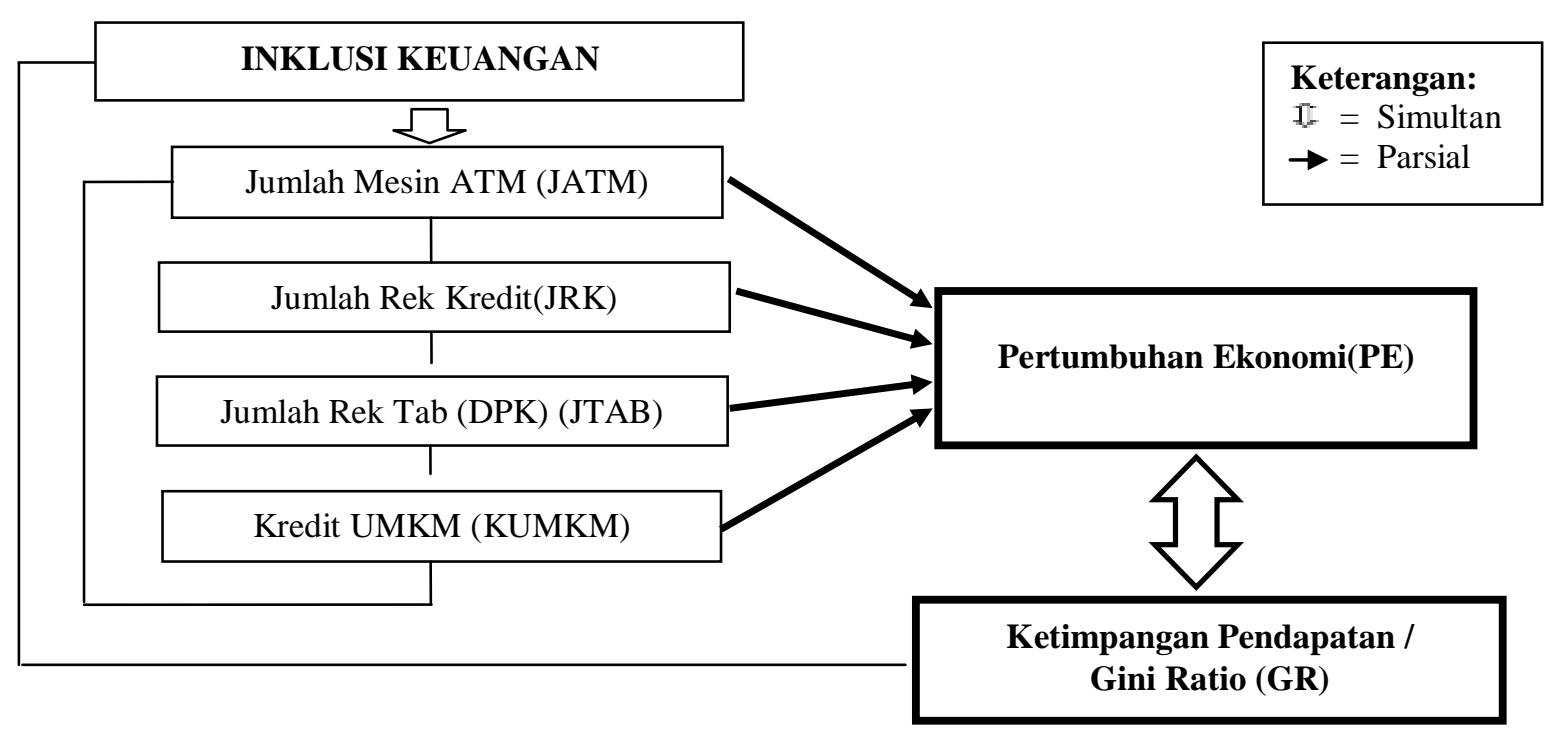

Gambar 1. Kerangka Penelitian

Sumber: Diolah peneliti, 2021. 
Tabel 1. Hasil Uji Identifikasi Persamaan Simultan

\begin{tabular}{ccccc}
\hline Persamaan & Nilai K $-\mathrm{k}$ & Syarat & Nilai $\mathrm{m}-1$ & Identifikasi \\
\hline 1 & $5-3$ & $>$ & $2-1$ & Overidentified \\
2 & $5-2$ & $>$ & $2-1$ & Overidentified \\
\hline
\end{tabular}

Sumber: Diolah peneliti, 2021.

Selanjutnya, persamaan (1) dan (2) di ubah menjadi persamaan bentuk reduksi (reduced form equations). Form ini bertujuan mencari variabel endogen dan variabel eksogen dari model yang akan dianalisis. Hasil reduced form untuk persamaan (1) dan (2) menjadi persamaan (3) dan (4) berikut:

$$
\begin{aligned}
\mathrm{PE}_{\mathrm{t}}= & \pi_{0 \mathrm{t}}+\pi_{\mathrm{J}} \mathrm{JATM}_{\mathrm{t}}+\pi_{2} \mathrm{JRK}_{\mathrm{t}}+\pi_{3} \mathrm{JTab}_{\mathrm{t}}+ \\
& \pi_{4} \mathrm{JKB}_{\mathrm{t}}+\pi_{5} \mathrm{JTab}_{\mathrm{t}}+\pi_{6} \mathrm{KUMKM}_{\mathrm{t}} \mathrm{v}_{\mathrm{t}} . .(3) \\
\mathrm{GR}_{\mathrm{t}}= & \pi_{7}+\pi_{8} \mathrm{JKB}_{\mathrm{t}}+\pi_{9} \mathrm{JTab}_{\mathrm{t}}+\pi_{10} \mathrm{JATM}_{\mathrm{t}}+ \\
& \pi_{11} \mathrm{JRK}_{\mathrm{t}}+\pi_{12} \mathrm{JTab}_{\mathrm{t}}+\pi_{13} \mathrm{KUMKM}_{\mathrm{t}}+ \\
& \mathrm{w}_{\mathrm{t}} \ldots \ldots \ldots \ldots \ldots \ldots \ldots \ldots \ldots \ldots \ldots \ldots \ldots \ldots \ldots \ldots \ldots \ldots \ldots \ldots \ldots \ldots
\end{aligned}
$$

Untuk mendapatkan perhitungan yang tepat dan juga mengurangi human error, digunakan bantuan program olah data Eviews 10 pada level of confidence sebesar 95 persen (atau, $\alpha=0,05$ ).

Di dalam persamaan simultan $\mathrm{M}$, suatu persamaan teridentifikasi jika mengeluarkan paling tidak m-1 variabel (endogen maupun eksogen) yang ada di dalam model. (Gujarati, 2015). Kriteria yang digunakan untuk menentukan persamaan simultan yaitu: (1) Jika $\mathrm{K}-\mathrm{k}=\mathrm{m}-1$, termasuk just identified dan diselesaikan dengan indirect least squares (ILS); (2) Jika K-k > m-1, termasuk overidentified dan diselesaikan dengan two-stage least squares (2SLS); atau, (3) Jika K-k < $\mathrm{m}-1$, termasuk unidentified atau tidak dapat diidentifikasi (Gujarati, 2015).

Berdasarkan hasil analisis seperti terlihat pada Tabel 1, maka dapat diketahui persamaan simultan dalam model adalah bersifat overidentified karena nilai K-k > m-1. Dengan demikian, persamaan simultan dalam penelitian ini sebaiknyaa diestimasi dengan metode Two-Stage Least Square (2SLS).

\section{HASIL ANALISIS \\ Uji Asumsi Klasik}

Keputusan terdistribusi normal tidaknya residual secara sederhana adalah dengan membandingkan nilai Probabilitas JB (JarqueBera)-hitung dengan tingkat alpha sebesar 0,05. Apabila nilai Prob. JB-hitung lebih besar dari 0,05 maka dinyatakan bahwa residual terdistribusi normal; namun sebaliknya, apabila nilainya lebih kecil maka tidak cukup bukti untuk menyatakan bahwa residual terdistribusi normal (Mansuri, 2016). Hasil analisis menunjukkan nilai Prob. JBhitung sebesar 0,833394>0,05 sehingga dinyatakan bahwa residual telah terdistribusi normal, yang artinya asumsi klasik terhadap problem kenormalan telah dipenuhi.

Untuk uji heterokedastisitas dilakukan terpisah antara persamaan pertama dengan persamaan kedua. Hasil uji Breusch-Pagan untuk persamaan pertumbuhan ekonomi, diperoleh nilai prob < chi sebesar 0,0848 adalah lebih besar dari derajat signifikansi $(0,05)$, yang berarti bahwa pada persamaan pertama tidak terjadi gejala heterokedastisitas. (Priyatno, 2016). Pada persamaan Gini Ratio, hasil uji Breusch-Pagan memperoleh nilai prob < chi sebesar 0,0909 adalah lebih besar dari derajat signifikansi $(0,05)$; yang berarti bahwa pada persamaan kedua ini juga tidak terjadi gejala heterokedastisitas.

Berikutnya dilakukan uji autokorelasi, yaitu problem yang terjadi bila nilai gangguan dalam periode tertentu berhubungan dengan nilai gangguan sebelumnya (Mansuri, 2016). Hasil untuk persamaan pertama memperoleh bahwa nilai probabilitas F-hitung lebih besar dari alpha $(0,05)$ sehingga dinyatakan bahwa 
persamaan tentang hubungan ketimpangan pendapatan dengan pertumbuhan ekonomi adalah tidak mengalami problem autokorelasi. Namun, hasil uji untuk persamaan kedua mengenai hubungan pertumbuhan ekonomi dengan ketimpangan pendapatan diperoleh nilai Prob. sebesar 0,0010 lebih kecil dari alpha $(0,05)$ sehingga dinyatakan terjadi autokorelasi. Untuk mengatasi masalah ini, maka diterapkan fungsi persamaan regresi yang baru dalam bentuk log atau first difference (Mansuri, 2016). Hasil pengujian ulang memperoleh nilai Prob. sebesar 0,5472 lebih besar dari alpha $(0,05)$ sehingga dinyatakan bahwa pada persamaan kedua tidak lagi mengalami persoalan autokorelasi.

\section{Analisis Persamaan Simultan Pertama}

Pada bagian ini dijabarkan tahapan analisis estimasi persamaan simultan melalui 2SLS. Untuk persamaan pertama mengenai pengaruh pertumbuhan ekonomi terhadap ketimpangan pendapatan diperoleh hasil empiris yang terangkum dalam Tabel 2.

Berdasarkan Tabel 2 diperoleh bahwa berdasarkan nilai koefisien regresi, hanya variabel JTAB yang memiliki pengaruh positif terhadap pertumbuhan ekonomi. Hasil ini berarti apabila JATB mengalami kenaikan maka pertumbuhan ekonomi juga mengalami kenaikan; sebaliknya bila JATB mengalami penurunan maka pertumbuhan ekonomi juga mengalami penurunan.

Sementara itu, variabel-variabel JATM, JRK, KUMKM dan GR diperoleh memiliki pengaruh negatif terhadap pertumbuhan ekonomi, yang berarti apabila salah satu variabel itu mengalami kenaikan, dengan asumsi variabel-variabel yang lain tidak mengalami perubahan, maka pertumbuhan ekonomi akan mengalami penurunan. Atau sebaliknya, apabila salah satu variabel itu mengalami penurunan, dengan asumsi bahwa variabel-variabel yang lain tidak mengalami perubahan, maka pertumbuhan ekonomi akan mengalami kenaikan.

Tabel 2 juga mengidentifikasi lebih jauh bahwa hanya variabel JATM yang memiliki pengaruh signifikan terhadap pertumbuhan ekonomi, dimana nilai Prob. $t<0,05$ (Ghozali, 2016). Sementara itu, keempat variabel lainnya yaitu JRK, JTAB, KUMKM dan GR secara parsial memiliki pengaruh tidak signifikan atas pertumbuhan ekonomi karena nilai Prob. $t$ yang dimiliki lebih besar dari 0,05 (Ghozali, 2016). Secara simultan, karena nilai Prob. $\mathrm{F}<0,05$, maka dinyatakan bahwa kelima variabel itu secara bersamasama berpengaruh secara signifikan terhadap pertumbuhan ekonomi (Ghozali, 2016). Hasilini menyatakan hipotesis pertama ditolak.

Nilai Adjusted R-Square sebesar 0,5324 menunjukkan bahwa kelima variabel yang tercakup dalam persamaan pertama ini berkontribusi relatif besar yaitu 53,24 persen dalam menjelaskan perubahan-perubahan yang terjadi pada pertumbuhan ekonomi; sementara sisanya sebesar 46,76 persen menyatakan masih ada sejumlah variabel lain yang tidak tercakup dalam persamaan pertama ini namun dinilai juga turut mempengaruhi fluktuasi pertumbuhan ekonomi .

\section{Analisis Persamaan Simultan Kedua}

Analisis untuk persamaan kedua tentang pengaruh ketimpangan pendapatan terhadap pertumbuhan ekonomi melalui teknik 2SLS diperoleh hasil empiris yang terangkum dalam Tabel 3.

Berdasarkan Tabel 3 diperoleh bahwa berdasarkan nilai koefisien regresi, hanya variabel JTAB yang memiliki pengaruh negatif terhadap ketimpangan pendapatan. Hasil ini berarti apabila JATB mengalami kenaikan maka ketimpangan pendapatan akan mengalami kenaikan; sebaliknya bila JATB mengalami penurunan maka ketimpangan pendapatan mengalami kenaikan. 
Tabel 2. Hasil Estimasi Persamaan Simultan Pertama

\begin{tabular}{lcccc}
\hline \multicolumn{1}{c}{ Variabel } & Coefficient & t-Statistics & Prob. $t$ & Hasil \\
\hline JATM & -0.039405 & -2.557198 & 0.0180 & Negatif dan Signifikan \\
JRK & -0.013744 & -1.278310 & 0.2145 & Negatif dan Tidak Signifikan \\
JTAB & 0.000576 & 0.958739 & 0.3481 & Positif dan Tidak Signifikan \\
KUMKM & -0.209876 & -0.737802 & 0.4684 & Negatif dan Tidak Signifikan \\
GR & -5.970134 & -0.239927 & 0.8126 & Negatif dan Tidak Signifikan \\
\hline F-statistics & 6.833861 & & & \\
Prob. F & 0.000551 & & & \\
R-Square & 0.619020 & & & \\
Adjusted $R$-Square & 0.532434 & & & \\
\hline
\end{tabular}

Sumber: Data sekunder (diolah), 2021.

Tabel 3. Hasil Estimasi Persamaan Simultan Kedua

\begin{tabular}{lcccc}
\hline \multicolumn{1}{c}{ Variabel } & Coefficient & t-Statistics & Prob. $t$ & Hasil \\
\hline PE & 0.012420 & 2.300686 & 0.0304 & Positif dan Signifikan \\
JKB & 0.000749 & 1.574672 & 0.1284 & Positif dan Tidak Signifikan \\
JTAB & $-3.15 \mathrm{E}-05$ & -9.576575 & 0.0000 & Negatif dan Signifikan \\
\hline F-statistics & 37.14102 & & & \\
Prob. F & 0.000000 & & & \\
R-Square & 0.810959 & & & \\
Adjusted R-Square & 0.787329 & & & \\
\hline
\end{tabular}

Sumber: Data sekunder (diolah), 2021.

Sementara itu, Tabel 3 menunjukkan bahwa variabel-variabel PE dan JKB diperoleh memiliki pengaruh positif terhadap ketimpangan pendapatan. Hal ini berarti apabila salah satu dari ketiga variabel itu mengalami kenaikan, dengan asumsi variabel yang lain tidak mengalami perubahan, maka ketimpangan pendapatan akan mengalami kenaikan. Sebaliknya, apabila salah satu variabel itu mengalami penurunan, dengan asumsi variabel-variabel yang lain tidak mengalami perubahan, maka ketimpangan pendapatan juga mengalami penurunan.

Tabel 3 juga mengidentifikasi ada dua variabel yang memiliki pengaruh signifikan terhadap ketimpangan pendapatan, yaitu PE serta JTAB karena masing-masing memiliki nilai Prob. $t$ lebih kecil dari 0,05 (Ghozali, 2016). Sementara itu, satu variabel lainnya yaitu JKB diperoleh secara parsial memiliki pengaruh tidak signifikan atas ketimpangan pendapatan karena memiliki nilai Prob. $t>$ 0,05 (Ghozali, 2016). Secara simultan, karena nilai Prob. $\mathrm{F}<0,05$ pada persamaan kedua, maka dinyatakan bahwa ketiga variabel tersebut secara bersama-sama berpengaruh signifikan terhadap ketimpangan pendapatan (Ghozali, 2016). Hasil- hasil ini menyatakan hipotesis kedua ditolak.

Nilai Adjusted R-Square sebesar 0,7873 menunjukkan bahwa ketiga variabel yang tercakup dalam persamaan kedua ini berkontribusi relatif sangat besar yaitu 78,73 persen dalam menjelaskan perubahan pada ketimpangan pendapatan; sementara sisanya sebesar 21,27 persen menyatakan masih ada sejumlah variabel lain yang tidak tercakup dalam persamaan kedua ini namun dinilai turut mempengaruhi fluktuasi yang terjadi atas ketimpangan pendapatan. 


\section{Pembahasan}

Hubungan Pertumbuhan Ekonomi dengan Inklusi Keuangan dan Gini Ratio

Hasil penelitian menunjukkan gini ratio atau ketimpangan pendapatan mempunyai pengaruh yang negatif dan tidak signifikan terhadap pertumbuhan ekonomi. Hal ini berarti ketika ketimpangan pendapatan naik maka akan menurunkan besaran pertumbuhan ekonomi. Hal ini sesuai dengan argumen Greenwood \& Jovanovic (1990) menjelaskan sebuah teori terkait hubungan pembangunan pada sektor keuangan dengan distribusi pendapatan. Dalam tahapan pembangunan, pertumbuhan ekonomi cenderung mengalami perlambatan seiring dengan meningkatnya tingkat pendapatan sektor keuangan yang semakin luas, sehingga struktur keuangan emakin berkembang, tingkat pertumbuhan ekonomi semakin cepat dan ketimpangan pendapatan juga semakin melebar.

Hasil penelitian ini juga menunjukkan jumlah mesin ATM mempunyai pengaruh yang negatif dan signifikan terhadap pertumbuhan ekonomi. Hal ini berarti ketika jumlah mesin ATM bertambah maka akan menurunkan besaran pertumbuhan ekonomi. Penyebab selanjutnya yaitu dimensi ketersediaan di Indonesia mengenai layanan perbankan yang masih terbatas di perkotaan, sehingga inklusivitas keuangan belum secara maksimal dapat dimanfaatkan oleh seluruh lapisan masyarakat.

Namun demikian, hasil penelitian ini tidak sejalan dengan studi Ang (2010) mengenai pengembangan keuangan di India yang menemukan bahwa semakin intensifnya distribusi cabang bank semakin menyeluruh yang diluncurkan pemerintah India selama periode 1977-1990 secara signifikan meningkatkan akses kaum miskin ke sektor keuangan formal sehingga dapat mengurangi ketimpangan pendapatan. Sedangkan yang terjadi di Indonesia menurut data OJK (2017) menunjukkan bahwa persebaran ATM dan kantor cabang di Indonesia belum merata baik kantor cabang maupun ATM di Indonesia belum sepenuhnya dapat menyentuh ke pelosok, dikarenakan ATM dan kantor cabang masih terkonsentrasi di pulau Jawa.

Berikutnya, hasil penelitian menemukan jumlah rekening kredit mempunyai pengaruh yang negatif dan tidak signifikan terhadap pertumbuhan ekonomi. Hal ini berarti ketika jumlah akun rekening kredit bertambah maka akan menurunkan pertumbuhan ekonomi. Hal ini akan tetapi tidak sejalan dengan penelitian Anwar \& Amri (2017) yang memperoleh bahwa jumlah rekening kredit berpengaruh positif terhadap PDB Indonesia, karena jika bank menyalurkan kredit yang tinggi kepada masyarakat maka tingkat kesempatan kerja juga akan semakin luas sehingga dengan pengambilan kredit ini juga akan dapat meningkatkan taraf hidup mereka.

Hasil penelitian ini juga menunjukkan jumlah rekening tabungan mempunyai pengaruh yang positif dan tidak signifikan terhadap pertumbuhan ekonomi. Hal ini berarti ketika jumlah akun rekening tabungan bertambah maka akan meningkatkan besaran pertumbuhan ekonomi Hal ini karena dana pihak ketiga yang diserap oleh bank dari masyarakat, digunakan kembali oleh bank untuk kegiatan perbankan dengan perjanjian.

Hasil penelitian ini menunjukkan kredit UMKM mempunyai pengaruh yang negatif dan tidak signifikan terhadap pertumbuhan ekonomi, yang berarti ketika kredit UMKM yang disediakan mengalami kenaikan maka akan menurunkan pertumbuhan ekonomi. Hasil telaah OJK (2017) mengenai potensi pertumbuhan ekonomi ditinjau dari penyaluran kredit perbankan kepada sektor prioritas ekonomi pemerintah, diargumentasikan tidak terdapat hubungan yang stabil antara kredit sektor prioritas atas pertumbuhan ekonomi secara nasional. 
Hubungan Ketimpangan Pendapatan dengan Pertumbuhan Ekonomi dan Inklusi Keuangan

Hasil penelitian ini mengenai pola hubungan tersebut menunjukkan pertumbuhan ekonomi mempunyai pengaruh yang positif dan signifikan terhadap level ketimpangan pendapatan. Hal ini berarti saat pertumbuhan ekonomi naik maka akan meningkatkan level ketimpangan pendapatan. Walau demikian, pertumbuhan ekonomi saat ini bukanlah patokan untuk mengurangi level kemiskinan, karena kenyataannya dengan menaiknya pertumbuhan ekonomi membuat ketimpangan pendapatan makin melebar.

Berdasarkan teori, meningkatnya tingkat pertumbuhan ekonomi seharusnya sejalan dengan berkurangnya tingkat ketimpangan pendapatan serta kemiskinan. Karenanya, bisa dinyatakan bahwa pertumbuhan ekonomi tidak dapat mengurangi level ketimpangan pendapatan. Argumen ini sependapat dengan hasil studi Istiqamah et al. (2018) yang menemukan bahwa pertumbuhan ekonomi berpengaruh positif dan signifikan terhadap ketimpangan pendapatan. Hal ini disebabkan pertumbuhan ekonomi tidak disumbangkan oleh setiap penduduk secara merata.

Hasil penelitian ini menunjukkan bahwa jumlah kantor cabang bank mempunyai pengaruh yang positif dan tidak signifikan terhadap ketimpangan pendapatan. Hal ini berarti ketika terjadi kenaikan jumlah kantor cabang bank maka akan bisa meningkatkan besaran ketimpangan pendapatan. Hasil ini sejalan dengan temuan empiris Anwar \& Amri (2017) bahwa semakin bertambah jumlah unit kantor bank yang tersebar di seluruh wilayah di indonesia maka juga akan mengakibatkan meningkatnya kemampuan bank dalam upaya menghimpun dana dari masyarakat yang berbentuk dana pihak ketiga (DPK). Dengan demikian, semakin bertambah juga kemampuan perbankan dalam menyalur- kan kredit kepada para anggota masyarakat yang kekurangan dana.

Selanjutnya, penelitian ini memperoleh temuan bahwa jumlah rekening tabungan mempunyai pengaruh yang negatif dan signifikan terhadap ketimpangan pendapatan. Hal ini berarti saat jumlah akun rekening tabungan (DPK) mengalami kenaikan maka akan menurunkan ketimpangan pendapatan. Studi empiris Anwar \& Amri (2017) juga menemukan hasil serupa bahwa semakin banyak jumlah kantor bank yang tersebar di seluruh wilayah maka akan meningkatkan kemampuan bank untuk menghimpun dana dari masyarakat yang berbentuk dana pihak ketiga (DPK) dalam jumlah lebih banyak. Dengan demikian, semakin besar pula kemampuan bank untuk menyalurkan DPK tersebut kepada masyarakat yang kekurangan dana dalam bentuk kredit.

\section{SIMPULAN}

Berdasarkan hasil-hasil empiris yang diperoleh di dalam penelitian ini, bisa disimpulkan beberapa manfaat yang bisa diperoleh melalui peran inklusi keuangan dalam mengatasi ketimpangan pendapatan. Pertama, inklusi keuangan berperan dalam meningkatkan stabilitas keuangan. Sebagai negara berkembang, peran inklusi keuangan sangat penting bagi sektor perbankan dan masyarakat, misalnya dapat menurunkan biaya intermediasi yang cukup tinggi, serta secara langsung dapat meningkatkan derajat kesejahteraan masyarakat.

Kedua, inklusi keuangan berperan dalam meningkatkan kemampuan masyarakat untuk berpartisipasi dalam kegiatan ekonomi, sehingga harapannya ini bisa menyelesaikan persoalan kemiskinan serta menurunkan tingkat kesenjangan. Ketiga, inklusi keuangan yang baik dapat menyumbangkan aktivitas ekonomi bagi masyarakat yang selama ini tidak tersentuh langsung dengan sistem 
perbankan, sehingga berdampak mengatasi masalah kemiskinan maupun kesenjangan. Keempat, inklusi keuangan bisa memberikan kesempatan kepada pihak perbankan dalam melakukan ekpansi pasar yang baru.

Manfaat kelima, inklusi keuangan juga berperan serta meningkatkan pembangunan ekonomi, salah satunya dengan membantu meningkatkan HDI (Human Development Index) atau meningkatkan pengetahuan dan tingkat harapan hidup masyarakat. Dengan adanya peningkatan HDI tersebut, maka dapat membuat kesenjangan sosial dan ketimpangan pendapatan yang tidak melebar dan pada akhirnya dapat membantu pemerintah dalam menurunkan tingkat kemiskinan masyarakat.

Merujuk beberapa kesimpulan tersebut, direkomendasikan perlu adanya intervensi dari pihak stakeholder atau pemerintah untuk membantu pendistribusikan pendapatan pada golongan masyarakat menengah kebawah dengan cara menciptakan lapangan kerja yang sesuai dengan tingkat pendidikan masyarakat miskin. Jika lapangan pekerjaan yang tersedia jauh lebih banyak untuk golongan masyarakat menengah keatas yang memiliki pendidikan tinggi, maka akan semakin sulit untuk meningkatkan tingkat pendapatan masyarakat golongan menengah kebawah, dan tentunya akan mengakibatkan melebarnya kesenjangan dalam ketimpangan pendapatan. Karena itulah mengapa pertumbuhan ekonomi yang tinggi sejalan dengan ketimpangan pendapatan yang tinggi juga.

\section{REFERENSI}

Amri, K. (2017). Analisis pertumbuhan ekonomi dan ketimpangan pendapatan: Data panel 8 provinsi di Sumatera. Jurnal EMT Kita, 1(1), 1-11. doi: 10.35870/emt.v1i1.22.

Ang, J. B. (2010). Finance and inequality: The case of India. Southern Economic Journal, 76(3), 738-761. Retrieved from www.jstor.org/stable/27751495.
Anwar, K., \& Amri,A. (2017). Pengaruh inklusi keuangan terhadap PDB Indonesia. Jurnal Ilmiah Mahasiswa Ekonomi Pembangunan, 2(3), 454-462. Retrieved from http://www.jim.unsyiah. ac.id/EKP/article/view/5719.

BPS. (2018). Produk domestik regional bruto, lapangan usaha. Retrieved from https://www.bps.go.id/subject/52/produ k-domestik-regional-bruto--lapanganusaha-.html.

Chambers, D. (2010). Does a rising tide raise all ships? The impact of growth on inequality. Applied Economics Letters, 17(6), 581-586. doi: 10.1080/135048 50802046971.

Ghozali, I. (2016). Aplikasi analisis multivariate dengan program IBM SPSS 23. BPFE Universitas Diponegoro.

Giorgi, G. M., \& Gigliarano, C. (2016). The Gini concentration index: A review of the inference literature. Journal of Economic Surveys, 31(4), 1-28. doi: 101111/Joes.12185.

Greenwood, J., \& Jovanovic, B. (1990). Financial development, growth, and the distribution of income. Journal of Political Economy, 98(5), 1076-1107. doi: 10.1086/261720.

Gujarati, D. N., Porter, D. C., \& Mandanugraha, E. (2015). Ekonometrika Dasar (Buku 1), Alihbahasa: Sita Wardhani S. \& C. Mangunsong. Salemba Empat

Istiqamah, Syaparuddin, \& Rahmadi, S. (2018). Pengaruh pertumbuhan ekonomi terhadap ketimpangan pendapatan dan kemiskinan (Studi provinsi-provinsi di Indonesia). $E$ Jurnal Perspektif Ekonomi Dan Pembangunan Daerah, 7(3), 111-126. doi: 10.22437/pdpd.v7i3.6903.

katadata. (2019). Indonesia Masih menghadapi ketimpangan ekonomi. Retrieved from https://databoks. katadata.co.id/datapublish/2019/04/13/i ndonesia-masih-menghadapiketimpangan-ekonomi. 
Lundberg, M. \& Squire, L. (2003). The simultaneous evolution of growth and inequality. The Economic Journal, 113(487), 326-344. Retrieved from https://www.jstor.org/stable/3590323.

Mansuri. (2016). Modul praktikum Eviews: Analisis regresi linier berganda menggunakan Eviews. Fakultas Ekonomi Universitas Borobudur.

Musfidar, M. (2001). Faktor-faktor yang mempengaruhi ketimpangan distribusi pendapatan di Sulawesi Selatan tahun 2001-2010. Skripsi. Fakultas Ekonomi dan Bisnis Universitas Hasanuddin. Retrieved from https://core.ac.uk/ download/pdf/25487407.pdf.

OJK. (2017). Hasil survei literasi dan inklusi keuangan nasional meningkat. Retrieved from https://sikapiuangmu. ojk.go.id/FrontEnd/CMS/Article/20549.

Priyatno, D. (2016). SPSS handbook. Mediakom.

Purba, M. F. (2016). Analisis keterkaitan indeks inklusi keuangan terhadap kemiskinan dan ketimpangan pendapatan Jawa Tengah 2010-2014. Skripsi. Universitas Diponegoro.

Raswita, N. P. M. E., \& Utama, M. S. (2013). Analisis Pertumbuhan Ekonomi dan Ketimpangan Pendapatan Antar Kecamatan di Kabupaten Gianyar. EJurnal Ekonomi Pembangunan Universitas Udayana, 2(3), 119-128, Retrieved from https://ojs.unud.ac.id/ index.php/eep/article/view/4290.
Rubin, A. \& Segal, D. (2015). The effects of economic growth on income inequality in the US. Journal of Macroeconomics, 45(September), 258-273. doi: 10.1016/ j.jmacro.2015.05.007.

Sarma, M. (2008). Index of financial inclusion. Working Paper No. 215. Indian Council for Research on International Economic Relations. Retrieved from http://www.icrier.org/ pdf/Working_Paper_215.pdf.

Ummah, B. B., Nuryantono, N., \& Anggraeni, L. (2015). Analisis inklusi keuangan dan pemerataan pendapatan di Indonesia. Jurnal Ekonomi dan Kebijakan Pembangunan, 4(1), 1-27. doi: 10.29244/jekp.4.1.2015.1-27.

Wahiba, N. F. \& El-Weriemmi, M. (2014). The relationship between economic growth and income inequality. International Journal of Economics and Financial Issues, 4(1), 135-143. Retrieved from https://www.researchgate.net/publication/285944967_The_R elationship_Between_Economic_Growt h_and_Income_Inequality.

World Bank. (2016). The World Bank databank. Data Bank. 